\title{
ANALISIS KECACATAN KEMASAN PRODUK OKKY JELLY DRINK PERISA BLACKCURRANT SEBAGAI UPAYA PERBAIKAN KUALITAS DENGAN METODE DMAIC PADA PT. TRITEGUH MANUNGGAL SEJATI
}

\author{
Suharto, Meutia \\ Program Studi Teknik Industri Fakultas Teknik \\ Universitas Tulang Bawang Lampung
}

\begin{abstract}
This study aims to determine and identify the causes of defects in the production process of PT. Triteguh Manunggal Sejati and know the level of sigma level. This research uses the six sigma method with the DMAIC approach as a quality control tool, which includes the Define, Measure, Analyze, Improve and Control stages.

Based on this study the results obtained are the level of sigma level at PT.Triteguh Manunggal Sejati is 4.96, which means that in the stage of sigma level the company has not reached the level of six sigma levels because in the production process at PT.Triteguh Manunggal Sejati still has product defects in the production process not yet achieved zero defect. The causes of product defects are based on cause and effect diagrams namely lid / seal defects are leaky lid, broken lid, and tilted lid.
\end{abstract}

Kata kunci : Defect, Six Sigma, DMAIC, cause and effect diagram

\section{Pendahuluan}

Industri makanan dan minuman merupakan sektor strategis yang akan terus tumbuh. Segmen yang menjanjikan yaitu pasar minuman. Pasar minuman ringan di Indonesia memiliki prospek yang besar untuk tumbuh. PT.Triteguh Manunggal Sejati merupakan industri minuman yang terletak di Jl.Ir Sutami km.6 desa campang raya Bandar Lampung. PT.Triteguh Manunggal Sejati berdiri sejak September 2012. PT.Triteguh Manunggal Sejati memiliki beberapa merk produk minuman jelly, yaitu minuman okky jelly berperisa jambu, minuman okky jelly berperisa mangga, minuman okky jelly berperisa jeruk, dan minuman okky jelly berperisa blackcurrant. Pemasaran produk okky jelly drink meliputi depo wilayah Sumbagsel yaitu Jambi, Palembang, Bengkulu, dan Lampung. Permintaan akan produk minuman jadi (minuman ringan) diprediksi akan terus meningkat, mengingat cuaca panas dan iklim tropis di Indonesia serta gaya hidup masyarakat kini cenderung beralih kepada minuman siap saji karena adanya kesibukan masyarakat.

Bentuk perbaikan di 
manufaktur yaitu dengan meminimalkan pemborosan dan berfokus pada penciptaan nilai. Pemborosan adalah segala hal yang tidak memberikan nilai tambah produk bagi konsumen. Shigeo Shingo dalam Hines dan Rich (1977) mengkategorikan pemborosan menjadi 7 macam, yaitu produksi berlebih, waktu tunggu, transportasi, proses yang tidak tepat, persediaan yang tidak perlu, gerakan yang tidak perlu, dan cacat produk.. Pemborosan yang terjadi pada proses produksi akan merugikan perusahaan, karena dapat menambah biaya total produksi dan menurunkan produktivitas perusahaan. Dengan meminimalisir pemborosan pada proses produksi, perusahaan dapat menghemat dan menekan biaya produksi karena sumberdaya digunakan secara efektif dan efisien dan berdampak pula pada peningkatan profit bagi perusahaan.

Six Sigma merupakan cara pendekatan kualitas terhadap TQM (Total Quality Management). TQM menjadi perhatian di Amerika Serikat tahun 80-an dan ini merupakan suatu respons terhadap superioritas kualitas dari pabrikan Jepang dalam bidang automotif dan penyejuk ruangan. Banyak studi pada bidang penyejuk ruangan mengemukakan bahwa kerusakan pada perusahaan Amerika Serikat lebih banyak dari perusahaan Jepang. Untuk membantu perusahaan supaya mampu memperbaiki program peningkatan kualitas, maka didirikan Malcolm Balridge National Quality Award dalam tahun 1987. Pada umumnya sistem pengendalian kualitas seperti TQM dan lain-lain hanya menekankan pada upaya peningkatan terus menerus berdasarkan kesadaran mandiri dari manajemen. Sistem tersebut tidak memberikan solusi yang tepat mengenai terobosan-terobosan atau langkah-langkah yang seharusnya dilakukan untuk menghasilkan peningkatan kualitas secara dramatik menuju tingkat kegagalan nol (zero defect). Six sigma sebagai salah satu metode baru yang paling popular merupakan salah satu alternatif dalam prinsip-prinsip pengendalian kualitas yang merupakan terobosan dalam bidang manajemen kualitas (Gasperzs,2005). Six sigma dapat dijadikan ukuran kinerja sistem industri yang memungkinkan perusahaan melakukan peningkatan yang luar biasa dengan terobosan strategi yang aktual. Six sigma juga dapat dipandang sebagai pengendalian proses industri yang berfokus pada pelanggan dengan memerhatikan kemampuan proses. Pencapaian Six sigma hanya terdapat 3,4 cacat per sejuta kesempatan. Semakin tinggi target sigma yang dicapai maka kinerja sistem industri semakin membaik. (Muhaimin,2012:1).

Mengingat PT. Triteguh Manunggal Sejati merupakan industri yang baru berdiri, maka dimungkinkan adanya beberapa aspek proses produksi yang belum berjalan atau belum sesuai dengan rencana yang dapat menimbulkan pemborosan selama proses produksi, dimana hal tersebut dapat merugikan perusahaan.

Pemborosan dapat ditemukan dalam bentuk apa pun dan dimana pun, seperti permasalahan pada proses produksi yang dihadapi PT. Triteguh Manunggal Sejati. Berdasarkan observasi awal, bentuk pemborosan yang terjadi pada proses produksi PT. Triteguh Manunggal 
Sejati yaitu pada pemborosan pada sisi waktu dan pada sisi kualitas produk. Pemborosan dalam sisi waktu yaitu berupa waktu berhenti (down time) pada saat proses produksi. Waktu berhenti terjadi karena adanya kurang isi atau kurang press sehingga

\section{Tinjauan Pustaka}

\section{Pengertian Kualitas}

Mengenai arti mutu/kualitas dapat berbeda-beda tergantung dari rangkaian perkataan atau kalimat dimana istilah mutu ini dipakai, dan orang mempergunakannya. Dalam perusahaan pabrik, istilah kualitas diartikan sebagai faktor-faktor yang terdapat dalam suatu barang/hasil yang menyebabkan barang/hasil tersebut sesuai dengan tujuan untuk apa barang atau hasil dimaksudkan atau dibutuhkan (Assauri, 1993: 267).

\section{Six Sigma}

Six Sigma adalah suatu filosofi manajamen yang terkenal di seluruh dunia. Tujuan dari Six Sigma adalah membuat kinerja suatu organisasi lebih efektif dan efesien. Saat ini metode penjagaan kualitas yang sedang berkembang adalah Six Sigma. Six Sigma adalah sebuah metode perbaikan kualitas berbasis stastistik yang memerlukan disiplin tinggi dan dilakukan secara komprehensif yang mengeleminasi sumber masalah utama dengan pendekatan DMAIC (DefineMeasure-Analize-Improve-Control). Six Sigma merupakan sistem yang komprehensif dan fleksibelitas untuk dilakukan pemberhentian untuk memperbaiki setting alat, dimana hal ini juga mempengaruhi kualitas produk.

mencapai, mempertahankan, dan memaksimalkan sukses bisnis. Six sigma secara unik dikendalikan oleh pemahaman yang kuat terhadap kebutuhan pelanggan, pemakaian yang disiplin terhadap fakta, data dan analisis statistik, dan perhatian yang cermat untuk mengelola, memperbaiki dan menanamkan kembali proses bisnis ( Peter S. Pande dkk,2003: xi).

\section{Analisa Hasil dan Pembahasan}

Dari hasil pengolahan data yang telah dilakukan, kemudian dilakukan analisa hasil perhitungan yang telah didapatkan. Analisis ini membahas hasil yang diperoleh dari pengolahan data menggunakan metode Six Sigma DMAIC. Sehingga dari pembahasan ini diperoleh rencana-rencana perbaikan untuk mengurangi permasalahan cacat produk di bagian filling.

1. Tahap define (pendefinisian masalah ) masalah kualitas dalam produk Okky Jelly drink berperisa blackcurrant, pada tahap ini yang menjadikan produk mengalami cacat didefinisikan penyebabnya.

2. Pemetaan proses produksi 


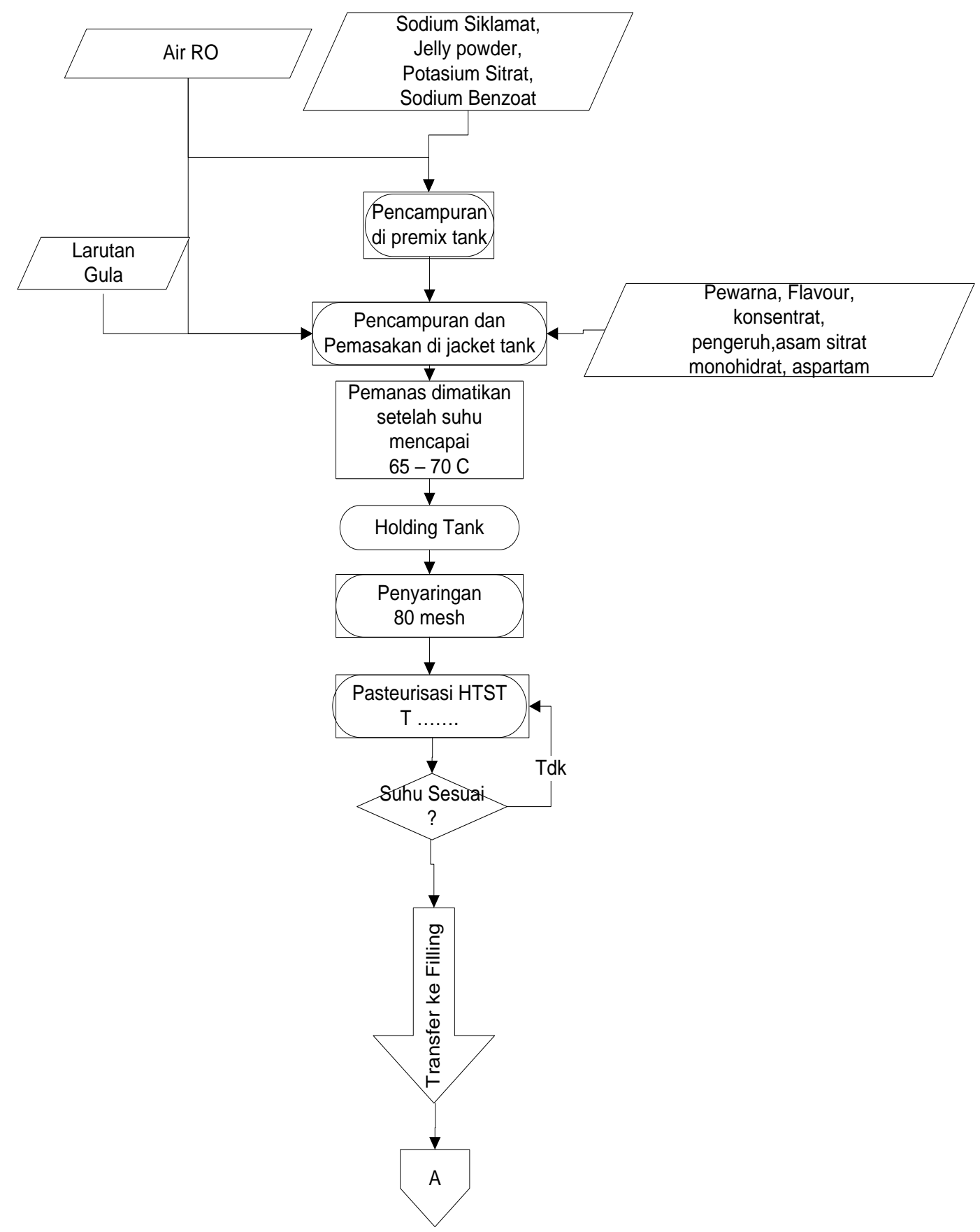




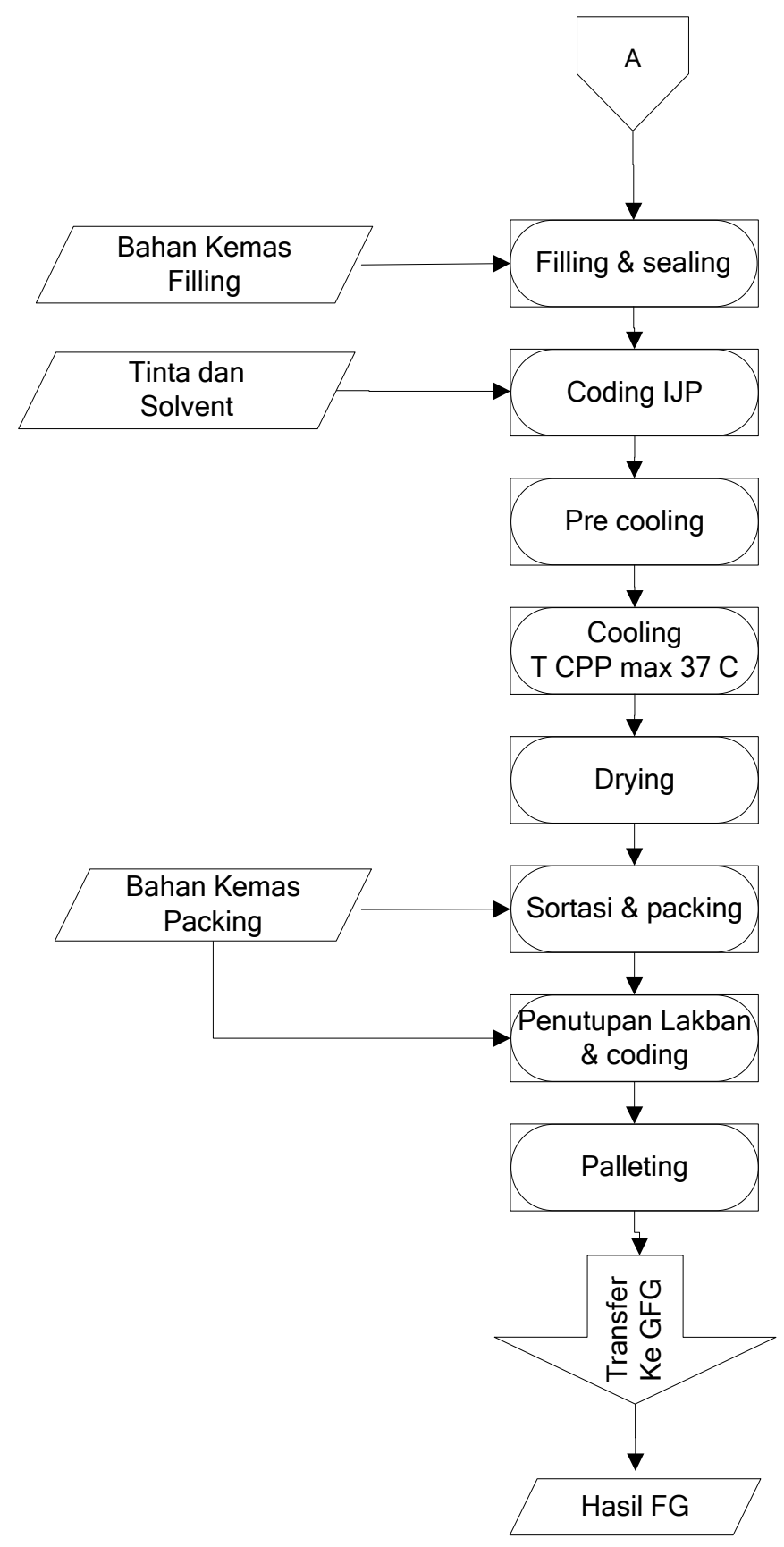

\section{Identifikasi Karakteristik Kualitas Okky Jelly Drink}

Tahap ini adalah untuk mengetahui Critical to Quality (CTQ) pada produk minuman Okky Jelly drink. berdasarkan hasil pengumpulan data dari perusahaan bahwa terdapat beberapa kecacatan produk yaitu :

a. Cacat Cup 
Cup adalah kemasan untuk produk air minum dalam kemasan yang didatangkan dari perusahaan yang memenuhi standar nasional dan pabrik minuman. Karakteristik jenis Cacat cup yaitu:

1. Cup penyok ini di karenakan oleh pada saat penyimpanan atau penyusunan cup yang kurang baik, baik karena ditendang saat penyusunan maupun tumpukan yang berlebih dari seharusnya maksimal dua tumpukan (gambar pada lampiran 1.1)

2. Cup gores atau cup tidak standar yaitu cup terdapat goresan baik itu dari suplyer ataupun dari proses penyusunannya yang sembarangan

3. Cup pecah, ini terjadi saat proses coding ataupun packing dimana terjadi benturan antar produk dan proses packing yang lama, sehingga cup jatuh dan pecah.

b. Cacat Lid/Seal

Lid adalah kemasan untuk penutup cup, lid ini juga di datangkan atau dipesan pada perusahaan lain. Untuk karakteristik jenis Cacat lid adalah berupa:

1. Bocor lid yaitu adanya lubang pada lid sehingga minuman jelly dalam produk keluar.

2. Lid kurang press/tidak rekat berupa pelekatan lid yang tidak sempurna/kurang rekat pada cup sehingga air dalam produk keluar.

3. Lid miring yaitu berupa pelekatan lid yang tidak sempurna dimana tulisan pada pinggir lid terpotong sebagian (gambar pada lampiran 1.2)

4. Seal/lid sobek dan melipat yaitu terjadi pada proses filling dimana proses sealing yang tidak sempurna menyebabkan seal sobek dan melipat.

c. Cacat volume

Pada perusahaan Triteguh Manunggal Sejati, karakteristik jenis Cacat volume yaitu berupa air didalam cup yang sudah direkatkan lid kurang dari tanda batas minimal pada cup yang telah ditentukan atau sering disebut dengan kurang isi.

\section{d. Tidak Ada Expired Date}

Tidak terdapat expired date pada kemasan okky jelly drink terjadi pada proses coding,dimana tinta solvent tidak terbaca/habis atau mesin IJP rusak. 
e. Suhu tidak standar

Suhu tidak standar terjadi di tangki HTST,dimana suhu harus mencapai $70^{\circ} \mathrm{C}$ dan suhu hopper tidak lebih dari $37^{\circ} \mathrm{C}$.

f. Brix tidak standar

Brix tidak standar terjadi pada proses cooking/pemasakan okky jelly drink dimana diukur menggunakan refraktometer.

\section{Pemilihan CTQ kunci}

Karakteristik kualitas (CTQ) kunci adalah CTQ yang paling berpengaruh terhadap kualitas produk kemasan, untuk penentuan karakteristik kualitas (CTQ) kunci adalah dengan data kecacatan produk Okky jelly drink berperisa blackcurrant pada bulan Juli 2015 dengan cara pembuatan diagram pareto untuk mengetahui frekuensi kecacatan yang paling tinggi yang nantinya digunakan sebagai karakteristik kualitas (CTQ) kunci. 
Data jumlah cacat produk minuman Okky jelly drink adalah sbb:

\begin{tabular}{|c|c|c|c|c|c|c|}
\hline \multirow[b]{2}{*}{ Tanggal } & \multicolumn{5}{|c|}{ Jenis Cacat (pcs) } & \multirow{2}{*}{$\begin{array}{c}\text { Jumlah } \\
\text { Cacat } \\
\text { (pcs) }\end{array}$} \\
\hline & $\begin{array}{c}\text { Cacat } \\
\text { Cup } \\
\end{array}$ & $\begin{array}{c}\text { Cacat } \\
\text { Lid }\end{array}$ & $\begin{array}{c}\text { Cacat } \\
\text { Volume }\end{array}$ & $\begin{array}{l}\text { Brix } \neq \\
\text { Standar }\end{array}$ & $\begin{array}{l}\text { Suhu } \neq \\
\text { standar }\end{array}$ & \\
\hline 1 & 0 & 0 & 0 & 0 & 0 & 0 \\
\hline 2 & 64 & 867 & 76 & 12 & 72 & 1091 \\
\hline 3 & 30 & 1006 & 20 & 19 & 64 & 1139 \\
\hline 4 & 54 & 922 & 29 & 15 & 72 & 1092 \\
\hline 5 & 22 & 1024 & 65 & 17 & 75 & 1203 \\
\hline 6 & 0 & 0 & 0 & 0 & 0 & 0 \\
\hline 7 & 25 & 966 & 62 & 15 & 68 & 1136 \\
\hline 8 & 49 & 1846 & 74 & 18 & 101 & 2088 \\
\hline 9 & 41 & 1518 & 113 & 29 & 498 & 2199 \\
\hline 10 & 50 & 1785 & 98 & 23 & 200 & 2156 \\
\hline 11 & 52 & 401 & 104 & 21 & 209 & 787 \\
\hline 12 & 31 & 475 & 44 & 16 & 49 & 615 \\
\hline 13 & 0 & 0 & 0 & 0 & 0 & 0 \\
\hline 14 & 36 & 765 & 36 & 13 & 71 & 921 \\
\hline 15 & 43 & 830 & 43 & 27 & 60 & 1003 \\
\hline 16 & 35 & 902 & 63 & 17 & 77 & 1094 \\
\hline 17 & 42 & 1001 & 57 & 15 & 97 & 1212 \\
\hline 18 & 32 & 639 & 51 & 10 & 70 & 802 \\
\hline 19 & 0 & 0 & 0 & 0 & 0 & 0 \\
\hline 20 & 0 & 0 & 0 & 0 & 0 & 0 \\
\hline 21 & 46 & 797 & 12 & 11 & 55 & 921 \\
\hline
\end{tabular}




\begin{tabular}{|c|c|c|c|c|c|c|}
\hline \multirow[b]{2}{*}{ Tanggal } & \multicolumn{5}{|c|}{ Jenis Cacat (pcs) } & \multirow{2}{*}{$\begin{array}{c}\text { Jumlah } \\
\text { Cacat (Pcs) }\end{array}$} \\
\hline & $\begin{array}{l}\text { Cacat } \\
\text { Cup }\end{array}$ & $\begin{array}{c}\text { Cacat } \\
\text { Lid }\end{array}$ & $\begin{array}{c}\text { Cacat } \\
\text { Volume }\end{array}$ & $\begin{array}{l}\text { Brix } \neq \\
\text { Standar }\end{array}$ & $\begin{array}{l}\text { Suhu } \neq \\
\text { standar }\end{array}$ & \\
\hline 22 & 28 & 833 & 28 & 32 & 101 & 1022 \\
\hline 23 & 32 & 964 & 36 & 25 & 67 & 1124 \\
\hline 24 & 0 & 0 & 0 & 0 & 0 & 0 \\
\hline 25 & 43 & 1008 & 39 & 59 & 94 & 1243 \\
\hline 26 & 30 & 480 & 24 & 10 & 29 & 573 \\
\hline 27 & 0 & 0 & 0 & 0 & 0 & 0 \\
\hline 28 & 104 & 1045 & 25 & 14 & 84 & 1272 \\
\hline 29 & 34 & 791 & 18 & 14 & 145 & 1002 \\
\hline 30 & 37 & 941 & 22 & 17 & 80 & 1097 \\
\hline 31 & 39 & 1029 & 19 & 13 & 84 & 1184 \\
\hline Total & 999 & 22835 & 1158 & 462 & 2522 & 27976 \\
\hline
\end{tabular}

Keterangan: $0=$ Tidak Produksi

Tahap Measure

Tahap

mesure

merupakan

langkah

operasional kedua dalam

program peningkatan kualitas

Six Sigma. Pada tahap ini

akan dilakukan pengukuran

kinerja proses dalam

menghasilkan produk Okky

jelly drink, langkah-langkah

yang dilakukan yaitu:

- Identifikasi Proses dengan Peta Kendali (P- Chart)

- Pengukuran level Six Sigma

\section{Tahap Analize}

Jenis permasalahan yang ingin dianalisa untuk diketahui penyebabnya diambil sesuai dengan hasil CTQ yang terseleksi yaitu cacat lid diantaranya lid miring, lid bocor dan lid pecah. Tingginya angka kecacatan tersebut pada akhirnya akan menyebabkan rendahnya kualitas produksi secara keseluruhan.

Membuat FMEA (Failure Mode and Effect Analysis)

Berdasarkan diagram sebab akibat pada gambar di atas, diketahui terdapat penyebabpenyebab terjadinya kecacatan produk. Langkah selanjutnya adalah merancang kuisioner yang bertujuan untuk mengetahui tingkat Severity, Occurence, dan Detection dari faktor penyebab 
kegagalan yang akan digunakan pada tahap analisis pengaruh potensial kegagalan sumber-

\section{Tahap Improve}

$\begin{array}{lr}\text { Merupakan } & \text { rencana } \\ \text { tindakan } & \text { untuk }\end{array}$
melaksanakan peningkatan kualitas Six sigma. Setelah mengetahui dimana pada tahap sebelumnya telah dilakukan identifikasi sumber-sumber dan akar penyebab dari masalah cacat tersebut, maka langkah selanjutnya adalah menetapkan suatu rencana perbaikan untuk mencegah penyebab-penyebab cacat itu terulang kembali sehingga dapat menurunkan jumlah cacat. Dalam tahap ini juga menggunakan FMEA dalam melakukan usulan rencana perbaikan (recommended action).

\section{Tahap Control}

Setelah dilakukan tindakan perbaikan, maka PT.Triteguh Manunggal Sejati perlu melakukan tindakan pengendalian terhadap perbaikan-perbaikan tersebut, terutama yang langsung berhubungan dengan proses.

\section{Kesimpulan}

Berdasarkan penelitian yang telah dilakukan di PT. Triteguh Manunggal Sejati departemen filling produk minuman okky jelly drink, maka dapat diambil kesimpulan sebagai berikut:

1. Untuk tingkat level sigma produksi minuman okky jelly drink bulan Juli 2015 pada PT. sumber variasi dengan menggunakan tool FMEA.

Triteguh Manunggal Sejati adalah 4,96 Sigma. Jadi, artinya dalam tahapan level sigma perusahaan belum mencapai tingkat level Six Sigma karena dalam proses produksinya masih mengalami adanya kecacatan produk yang belum mencapai zero defect.

2. Penyebab terjadinya kecacatan produk yaitu berdasarkan diagram sebab akibat cacat lid diantaranya :

1) bocor lid : Heater kurang Panas, heater terlalu panas, bucket dengan trimming tidak center, seal disk kotor dan operator kurang cermat.

2) Pecah lid : Lid getas dan handling kurang baik

3) Lid Miring : Kedudukan roll lid goyang dan operator kurang teliti

\section{Daftar Pustaka}

Assauri, Sofjan. 2008. "Manajemen

Produksi dan Operasi”

Lembaga Penerbit Fakultas

Ekonomi Universitas

Indonesia. Jakarta.

Baroto, Teguh. 2002. "Perencanaan dan Pengendalian Produksi”. Jakarta: Ghalia Indonesia.

Dewi, S. K. (2012). Minimasi Defect 
Produk Dengan Konsep Six

Sigma. Jurnal Teknik Industri.

Vol 13, 1: 43-50

Gaspersz, VINCENT (2002),

"Pedoman Implementasi

Program Six Sigma”, Jakarta,

PT. Gramedia Pustaka Utama.

Gaspersz, VINCENT (2001),

"Total

Quality

Management", Jakarta, PT.

Gramedia Pustaka Utama.

Khoirunnisa., \& Ganika, G.

(2012). “Analisis Kecacatan

Produk Sebagai Upaya

Perbaikan Kualitas Menuju

Zero Defect. Jurnal

Manajemen Dan Bisnis. Vol IX, 1”.

Komarudin., Saputra, R. (2011). "Analisis Cacat Produk Botol Kemasan Plastik Dengan
Menggunakan Metode Six Sigma Di PT. X. Jurnal Industri. Vol 04, 07, 2333".

Miranda Tunggal Amin Widjaja

(2002), "Six Sigma:

Gambaran Umum Penerapan

Proses dan Metode-Metode

Yang Digunakan Untuk

Perbaikan”,Jakarta, Harvindo.

Pande, Peter S, Robert P. Newman,

Roland R. Cavanagh (2002),

"The Six Sigma Way:

Bagaimana GE, Motorola dan

PerusahaanTerkenal Lainnya

Mengasah Kinerja Mereka", Yogyakarta, Andi.

Pyzdek, Thomas (2000), "The Six

Sigma Handbook", Jakarta, Salemba Empat. 